\title{
UNJUK KERJA TURBIN AIR KAKI ANGSA NEXT-G DENGAN VARIASI LEBAR SUDU DAN JUMLAH KAKI SUDU MENGGUNAKAN PENDEKATAN KOMPUTASIONAL
}

\author{
Muhamad Taufiq Hidayat, Retno Wulandari \\ Universitas Negeri Malang \\ Jl. Semarang No.5, Sumbersari, Kec. Lowokwaru, Kota Malang, Jawa Timur 65145, Indonesia \\ E-mail: muhamad.taufiq72@gmail.com
}

\begin{abstract}
This study to determine the efficiency of next-G geese foot turbine, the Angled Water mill is utilized in rural or remote areas, with potential rivers and local people to easily adopt the material. It is necessary to design a new turbine that can able to extract energy from free fluid flow or zero head water power resources. The design and material of the design was done using Computational Fluid Dynamics (CFD) software. The method is to know the most optimal modification of goat water turbine design from the variation in width and number of feet of NextG geese foot mill legs as follows: (1) 600; (2) $700 \mathrm{~mm}$; (3) $750 \mathrm{~mm}$, for the number of legs used 4 pieces, 6 pieces, 8 legs. The results of development the Next-G goose footwheel mill blade is the moments pressure value increased for the width of the water wheel blade $750 \mathrm{~mm}$, and the moments pressure decreases to $600 \mathrm{~mm}$. The number of feet 4 blade the pressure moment is increased and decreasing for the number of feet of 8 blade. The optimum moments pressure is applied to the width $750 \mathrm{~mm}$ waterwheel blade, and the number of 4 impeller feet.
\end{abstract}

Keywords: Water Turbine Goose Legs Next-G, Computational Fluids Dynamics (CFD)

\section{PENDAHULUAN}

Permintaan energi di Indonesia cenderung meningkat pesat sejalan dengan pertumbuhan ekonomi dan pertambahan penduduk. Berdasarkan data dari PT Perusahaan Listrik Negara (PLN) permintaan akan energi listrik terus meningkat dari tahun ke tahun. Pada tahun 2001, terjadi kenaikan permintaan listrik sebesar $6,4 \%$, disusul tahun 2002 menjadi 12,8\%. Diprediksikan sepuluh tahun kedepan, kenaikan permintaan menjadi $9 \%$ setiap tahunnya. Ironisnya, sumber energi konvensional berupa energi fosil yang merupakan sumber energi utama di Indonesia semakin terbatas cadangannya. Sampai tahun 2009, sebagian besar kebutuhan tenaga listrik di Indonesia masih dipasok dari pembangkit listrik berbahan bakar fosil. Minyak Bumi masih menduduki peringkat tertinggi, yaitu $51,66 \%$. Gas alam menduduki tingkat kedua, yakni $28,57 \%$. Sisanya dipasok dari energi minyak sebesar $15,34 \%$ dan energi terbarukan $4,43 \%$. Ketergantungan terhadap konsumsi energi berbahan bakar fosil dan belum termanfaatkannya sumber energi baru terbarukan merupakan salah satu kelemahan dalam menerapkan pemerataan kebijakan energy[1].

Selama ini kebutuhan energi bahkan kebutuhan dunia masih mengandalkan minyak bumi sebagai penyangga utama kebutuhan energi. Sementara itu tidak dapat dihindarkan bahwa sumber energi ini semakin langka dan mahal harganya. Air merupakan sumber energi yang dapat diperbaharui, sebagian besar wilayah indonesia merupakan air dan banyak sungai-sungai kecil didaerah pedalaman yang belum dimaksimalkan fungsinya. Pemanfaatan air yang bisa digunakan untuk menghasilkan tenaga listrik. $\mathrm{Di}$ Indonesia telah banyak dikembangkan pembangkit listrik dengan menggunakan turbin, namun kebanyakan turbin tersebut memanfaatkan tinggi jatuh air (head) sebagai penggeraknya, seperti air terjun dan air yang dibendung. Namun, tidak semua daerah di Indonesia memiliki potensi energi air dengan tinggi jatuh besar yang tinggi, tetapi hanya memiliki potensi energi air yang memiliki tinggi jatuh rendah atau memiliki energi kinetik aliran. 
Maka perlu dilakukan suatu upaya untuk metode Taguchi. Taguchi menghasilkan memanfaatkan potensi sumber energi aliran disiplin dan struktur dari disain eksperimen dan air untuk pembangkit listrik yaitu dengan juga dapat mengurangi jumlah pelaksanaan menggunakan turbin[2].

percobaan jika dibandingkan dengan

Kincir air merupakan salah satu bentuk mesin konversi energi, kincir air ini cocok digunakan untuk aliran air dengan debit yang tidak terlalu tinggi seperti yang ada di sungaisungai di daerah pedalaman yang membutuhkan aliran listrik skala kecil. Dengan memanfaatkan energi potensial air menjadi energi mekanik berupa putaran poros maka aliran listrik dapat dihasilkan[3].

Analisa pengaruh jumlah sudu turbin air kaki angsa next-G dengan variasi lebar dan jumlah kaki sudu menggunakan software Computational Fluid Dynamic (disingkat CFD). Beberapa peneliti di seluruh dunia telah merancang berbagai tipe turbin air lalu diuji dan dianalisa dengan bantuan aliran air sungai. Pengujian ini membutuhkan seperangkat peralatan dan membutuhkan biaya yang cukup mahal. Dengan bantuan software Analysis System (Ansys), para peneliti dapat menganalisa dan merancang turbin air yang lebih baik dan lebih murah dari segi biaya perancangan dengan hasil yang hampir sama bila dibandingkan dengan menggunakan air sungai langsung. Perancangan dengan menggunakan software CFD merupakan tolak ukur sebagai perkiraan dalam merancang dan membuat turbin air yang sebenarnya, oleh karena itu akan dilakukan analisa dengan menggunakan software Computational Fluid Dinamic (CFD)[3].

\section{METODOLOGI PENELITIAN}

Pemanfaatan turbin air kaki angsa Next$G$ dapat menaikkan efisiensi daya, terutama berdampak pada peningkatan kualitas hidup masyarat pedesaan pedalaman yang kurang dari jangkauan energi listrik terutama untuk memanfaatkan energi potensial air.

Pengembangan desain turbin air kaki angsa Next-G dilakukan dengan simulasi menggunakan software Computational Fluids Dynamics (CFD). Untuk mendapatkan hasil desain yang optimal dilakukan menggunakan

menggunakan percobaan full factorial, sehingga dapat menghemat waktu dan biaya.

Tahapan pengembangan desain dengan software Ansys sebagai berikut:

a. Pre-Processing, merupakan langkah pertama dalam membangun dan menganalisa sebuah model CFD. Teknisnya adalah membuat paket CAD, membuat mesh yang sesuai, kemudian menerapkan kondisi batas dan sifat-sifat fluidanya

b. Processing/Solving, solver (program inti pencari solusi) CFD menghitung kondisikondisi yang diterapkan pada saat preprocessing.

c. Post-Processing merupakan langkah terakhir dalam analisa CFD. Hal yang dilakukan pada langkah ini adalah mengorganisasi dan menginterpretasi data hasil simulasi CFD yang bisa berupa gambar, kurva, atau animasi.

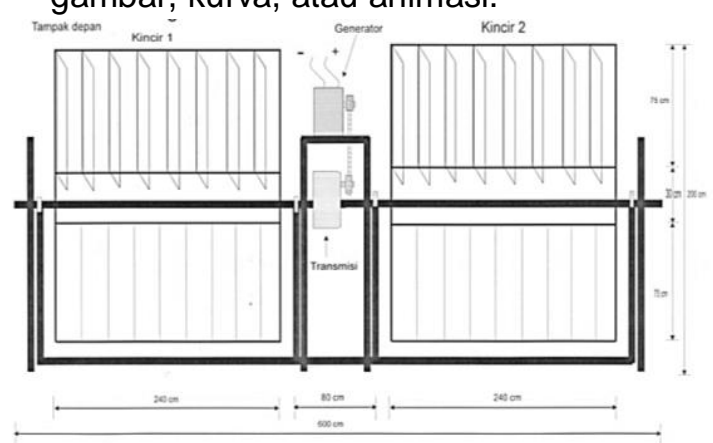

Gambar 1. Kincir air kaki angsa (tampak depan)

\section{HASIL DAN PEMBAHASAN}

Hasil analisis unjuk kerja pada desain kincir air kaki angsa, problem utama yang harus menjadi perhatian adalah bagaimana memanfaatkan secara efektif aliran fluida yang melalui kincir air sehingga menghasilkan efisiensi yang optimal. Hal tersebut bisa dicapai apabila desain kincir air memungkinkan aliran fluida yang melalui kincir air meningkat garis aliran lurusnya[4]. Desain kincir air seperti pada Gambar 1 dan 2. 
1. Pada Tahap pre-processing, dibuat model dalam paket CAD, model sudu dengan mesh yang sesuai dalam kondisi batas dan sifat-sifat fluida yang disesuaikan dengan kondisi free water flow. Seperti tampak pada Gambar 3.

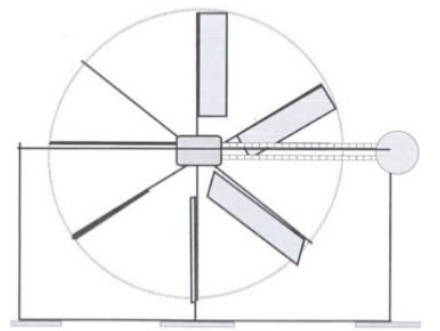

Gambar 2. Kincir air kaki angsa tampak samping

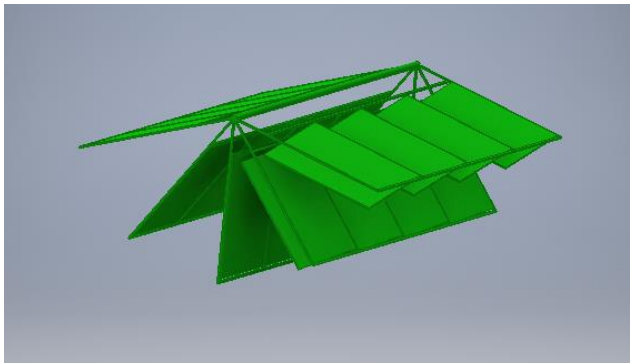

Gambar 3. Model geometri Turbin air kaki angsa next-G.

2. Pada tahap processing/solving: solvers (program inti pencari solusi) dari CFD memproses perhitungan-perhitungan dan persamaan matematika yang diterapkan sesuai dengan kondisi-kondisi yang diambil pada saat preprocessing. Hasil perhitungan seperti pada Gambar 4.

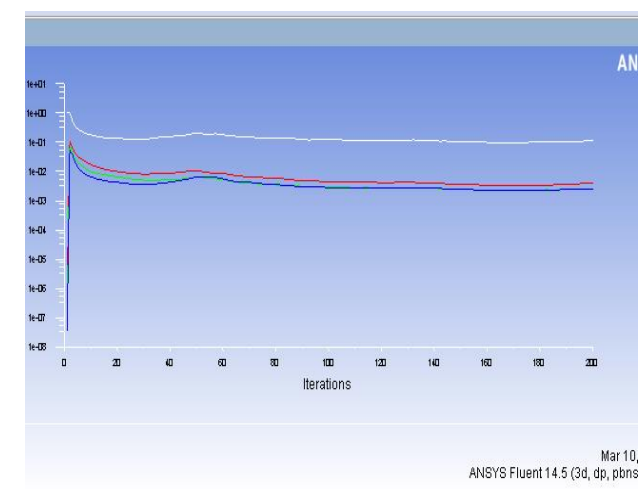

Gambar 4. Iterasi dari simulasi Kincir air kaki angsa Next-G
3. Post-Processing: mengorganisasi dan menginterpretasi data hasil simulasi CFD yang berupa gambar, kurva, dan animasi. Seperti tampak pada Gambar 5.
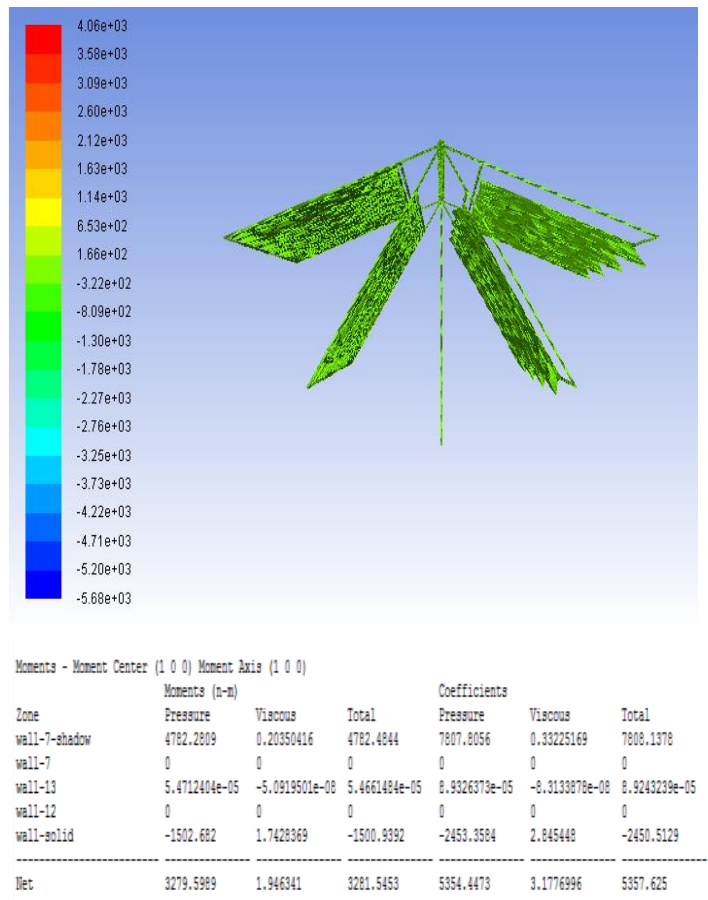

Gambar 5. Hasil Iterasi untuk Kontur tekanan pada simulasi Kincir air Kaki angsa Next-G.

Hasil iterasi dari kontur tekanan pada simulasi turbin air kaki angsa next-G ditampilkan pada Tabel 1 berikut:

Tabel 1. Hasil iterasi dari kontur tekanan pada simulasi turbin air kaki angsa next-G

\begin{tabular}{ccccc}
\hline No & $\begin{array}{c}\text { Jumla } \\
\text { h Kaki } \\
\text { Sudu }\end{array}$ & $\begin{array}{c}\text { Lebar } \\
\text { Sudu } \\
\text { (mm) }\end{array}$ & $\begin{array}{c}\text { Kecepatan } \\
\text { Air } \\
\text { (m/detik) }\end{array}$ & $\begin{array}{c}\text { Moments } \\
\text { Pressure } \\
\text { (NM) }\end{array}$ \\
\hline 1. & 4 & 600 & 0,6 & 310,86567 \\
2. & 4 & 700 & 0,7 & 1482,4976 \\
3. & 4 & 750 & 0,8 & 3279,5989 \\
4. & 6 & 600 & 0,7 & 463,14024 \\
5. & 6 & 700 & 0,8 & 1384.2107 \\
6. & 6 & 750 & 0,6 & 1832,7167 \\
7. & 8 & 600 & 0,8 & 572,65473 \\
8. & 8 & 700 & 0,6 & 152,00871 \\
9. & 8 & 750 & 0,7 & 2477,3544 \\
\hline
\end{tabular}


Berdasarkan hasil pengembangan dari desain sudu turbin air kaki angsa next-G didapatkan nilai moment pressure meningkat untuk lebar sudu turbin air kaki pada lebar 750 $\mathrm{mm}$, dan nilai momen pressure menurun untuk lebar $700 \mathrm{~mm}$ dan $600 \mathrm{~mm}$. Sehingga didapatkan moment pressure optimal yaitu dengan jumlah kaki sudu 4 dengan lebar 750 $\mathrm{mm}$.

Berbeda dengan perhitungan Gorban dkk, Betz [6], dengan menggunakan teori momentum yang berdasarkan prinsip hukum fisika dasar, mendapatkan bahwa energi yang dapat diekstrak dari aliran fluida yang melewati penampang melintang kincir air adalah dengan energi yang terdapat pada aliran fluida. Lebih jauh Bezt menemukan bahwa daya optimal yang dapat diekstrak dari aliran fluida tergantung dari rasio antara kecepatan aliran di depan kincir air dengan kecepatan aliran setelah melewati konverter, dengan prinsip ini, Bezt mendapatkan efisiensi maksimum 59,3\%.

\section{KESIMPULAN}

Berdasarkan penelitian yang sudah dilakukan, didapatkan bahwa pengembangan desain lebar dan jumlah kaki sudu turbin air kaki angsa Next-G adalah sebagai berikut

1. Nilai moment pressure meningkat pada lebar sudu $750 \mathrm{~mm}$ dengan jumlah kaki 4

2. Nilai moment pressure menurun untuk lebar $700 \mathrm{~mm}$, dan $600 \mathrm{~mm}$ dengan jumlah kaki 6 dan 8 .

3. Didapatkan moment pressure optimal adalah pada lebar sudu $750 \mathrm{~mm}$ dengan jumlah kaki 4.

\section{DAFTAR PUSTAKA}

[1] Ai Yuningsih. 2011, Potensi Energi Arus Laut untuk Pembangkit Listrik di Kawasan Pesisir Flores Timur NTT. IImu dan Teknologi Kelautan Tropis. Vol.3, No.1, Hal. 13-15.

[2] Agus,S. 2000, Prospek Penggunaan Teknologi Bersih Untuk Pembangkit Listrik dengan Bahan Bakar Batu Bara di Indonesia, Teknologi Lingkungan. Vol.3, No. 1 Hal 90-95.

[3] Thoharudin, 2014, Optimasi Tinggi Tekan Dan Efisiensi Pompa Sentrifugal Dengan Perubahan Jumlah Sudu Impeler dan Sudut Sudu Keluar Impeler ( $\beta 2)$ Menggunakan Simulasi Computational Fluid Dynamics, Yogyakarta Seminar Nasional Aplikasi Sains dan Teknologi 2014, 1st AKPRIND.

[4] Djajusman, H. 2011. Kincir Air Kaki Angsa. M\&E. Vol.9, No.4

[5] Gorban, A., Braverman, $M$ and Silantyev, V. 2002. Modifed Kirchhoff Flow with a Partially Penetrable Obstacle and Its Aplication to the Efficiency of Free Flow Turbines. Mathematical and Computer Modelling 35:1371-1375.

[6] Gorban, A.N., Garlov, A.m. And Silantyev, V.M. 2001. Limits of the turbine Eficiency for Free Fluid Flow. Journal of Energy Resources Tecnology, Vol.123. 2001.

[7] Hau E, 2006, Wind Turbines : Fundamentals Technologies, Application, Economics.2nd Edition, Springer-Verlag Berlin Heidelberg.

[8] Retno Wulandari, 2015, Pemanfaatan Energi Air Pedesaan Melalui Pengembangan Desain Sudu Kincir Air Kaki Angsa Next-G. 